\title{
The Future of the International Monetary System
}

by Ansgar Belke, Kerstin Bernoth and Ferdinand Fichtner

The financial crisis of 2007/2008 and the current "Euro crisis" challenge the current global monetary system. They drastically reveal the actual system's weaknesses und show the eminent importance of the international monetary system for the stability of markets and national economies. DIW Berlin was commissioned by the Federal Ministry of Finance to research possible alternatives to the existing exchange rate regime. In principle, neither of the two extremes completely free or fixed exchange rates - is suitable. A mixed system is preferable - with improvements to the status quo, though. An exchange rate regime with few big currency areas, which are linked to each other with flexible exchange rates, should be the aim of reforms. This should correspond to a multi-polar key currency system with the currently dominating US Dollar and the Euro as well as the Chinese Renmimbi as most important actors. These developments should be accompanied by substantial improvements in the regulatory framework of the financial markets. Necessary elements are a reinforced global and especially European economic coordination and an internationally agreed-on, assertive financial market authority.

1 This report is based on a comprehensive study on the same topic carried out by DIW Berlin on behalf of the Federal Ministry of Finance. See Belke, A., Bernoth, K., Fichtner, F. (2011): Die Zukunft des internationalen Währungssystems. DIW Berlin: Politikberatung kompakt (currently being published).
Over the past 150 years, the global monetary system has seen a number of varying degrees of links between different currencies (Box I). Periods of very strong ties between the main currencies of the global economy (like during the gold standard or the Bretton Woods system) alternated (at least shortly) with regimes of relatively high flexibility of exchange rates (mostly after the breakdown of relatively narrow regimes), e.g. after the end of the gold standard in the I920s and when the intra-European exchange rates became much more flexible following the collapse of the European currency system at the beginning of the I99os. From a global perspective, there has been a tendency towards more flexible exchange rates in the past years. ${ }^{2}$

\section{Advantages and Disadvantages of Flexible and Fixed Exchange Rates}

The global economic and financial crisis has caused doubts about the existing global exchange rate system. Strong fluctuations in exchange rates, be it between the US Dollar and the Euro or Eastern European currencies, regularly lead to financial market uncertainties, while at the same time fixed exchange rates like between China and the USA support the build-up of massive imbalances. In principle, two extreme forms of exchange rate regimes can be imagined: Full flexibility and a complete fixing of global exchange rates. Full flexibility would hold the advantage of combating global imbalances and the spill-over of economic ups and downs. With flexible exchange rates, a country's current account surplus leads to the appreciation of the local currency because of higher demand for the domestic currency. This makes exports more expensive on the global market, whereas prices for imports go down from the country's own perspective. As a consequence, the foreign trade surplus diminishes. An excessive, permanent export surplus of

2 The establishment of the European Monetary Union obviously works against this trend. 
the type we observe in case of the Chinese economy is less probable in a system of flexible exchange rates.

In many other emerging countries, this connection works the other way around: Based on their high economic growth, domestic demand and imports as well as domestic consumption are strong, causing a high current account deficit, which is mitigated by devaluation.

On the whole, flexible exchange rates can contribute to an improved resource allocation because of their ability to quickly adapt to new economic conditions. In the role of automatic stabilizers they mitigate international spill-overs of price and cyclical fluctuations, reduce insecurity and, thus, promote investment activity. ${ }^{4}$ Even more so, flexible exchange rates allow for an independent monetary policy ${ }^{5}$ which is able to respond to national economic ups and downs and to contribute to domestic economic stabilization and better framework conditions for economic growth on the whole.

On the other hand, there are a number of reasons for further international stabilization of exchange rates. Even the introduction of a global currency has its followers, even among economists. ${ }^{6}$ The main argument in favor of fixed exchange rates or a global currency is efficiency. Growing international transparency contributes to stronger trade flows and more intense use of the advantages of international division of labor. Furthermore, real economic investment activity can increase, since international investments become more attractive with declining risk premia (because of the end of exchange rate risks). Both connections have the capacity to promote growth, with the growth dynamic in this case resulting from the stabilization of international economic relations in contrast to a flexible exchange rate regime.

3 Examples for such emerging countries with high current account deficits are India and Brazil. China is somehow atypical because of its export-driven growth and the resulting current account surplus.

4 See Friedman, M. (1953): The Case for Flexible Exchange Rates. In: Essays in Positive Economics, University of Chicago Press, Chicago, 157-203. The precondition for mitigated price fluctuations is the endogenous reaction of exchange rates to changed foreign prices. But if exchange rates are understood as a variable which is for example influenced by capital markets, changing exchange rates may also cause destabilizing influence. See also Meese, R.A. and Rogoff, K. (1983): Empirical Exchange Rate Models of the Seventies: Do They Fit out of Sample? Journal of International Economics, 14, 3-24. They demonstrate that exchange rates fluctuate more frequently than justified by fundamental data.

5 The currency trilemma points out that fixed exchange rates are not possible with an autonomous monetary policy and free movement of capital. See the fundamental article by Mundell, R. (1962): Capital Mobility and Stabilization Policy under Fixed and Flexible Exchange Rates. In: Canadian Journal of Economic and Political Science, Vol. 29, 475-485.

6 See e.g. the web site of Robert Mundell, Nobel prize winner in Economics and advocate of a global currency, for a list of academic publications: http:// robertmundell.net/economic-policies/world-currency/.
The disadvantages of a fixed exchange rate regime or its extreme case - a global currency - can be deducted from the described advantages of a flexible exchange rate system. Especially the danger of excessive current account imbalances is a lot higher with fixed exchange rates. This is especially true when national economies in different stages of development come together.

The French G2o presidency introduced the concept of "Bretton Woods II"7 - an effort to remodel the global monetary system named after the I944 agreement for a post-war monetary order. This concept aims for stronger ties between the exchange rates of the big industrialized and emerging countries. At least G2o members were to agree on exchange rate corridors. But if we look closely, such a regime does not seem beneficial: It would probably hold both the disadvantages of flexible exchange rates and the disadvantages of fixed exchange rates. Exchange rate corridors (in contrast to really fixed exchange rates) do not solve the problem of exchange rate induced insecurity. Short-term fluctuations especially on the capital markets could still lead to sudden reversals of capital flows,. The problem of imbalances building up is not solved either. In a world with several economic centers (USA, Eurozone, China, South America etc.), which develop quite differently, such a rigid system is doomed to fail.

\section{Mixed System Still Best Alternative}

The status quo regime as a mixed system with the US Dollar as central anchor currency in international trade and capital movement is probably not the worst solution. However, we learn from the developments especially of the last decade, that excessive imbalances between national economies in different stages of development need to be prevented with flexible exchange rates. A (possibly limited) flexibilization of the Chinese Renminbi in relation to the US Dollar would be desirable in order to mitigate the enormous Chinese current account surplus (as well as its mirrored excessive US deficit) through the revaluation of the Chinese currency.

At the same time, the advantages of fixed exchange rates should be used in global trade. According to calculations by DIW Berlin, fixed exchange rates hold significant positive growth effects, especially for industrialized countries. The reason is their strong exposure to internatio-

7 The term "Bretton Woods II" is not clearly defined. The name is sometimes also used for the pre-crisis monetary system with the US Dollar as key currency and fixed exchange rates to emerging countries, which showed some parallels to the post-war system. See e.g. Dooley, M.P. et al. (2004): The Revised Bretton Woods System. In: International Journal of Finance and Economics, Vol. 9, 207-313 
Box 1

\section{Global Monetary Systems before the Crisis}

\section{The Gold Standard (1871-1914)}

From a historic perspective, the gold standard was probably the most comprehensive international monetary system. Its center piece was the guarantee of stable exchange rates for the conversion of national currencies in gold. In order to ensure this fixed convertibility, the member states of the gold standard were obliged to keep currency reserves. Despite a lack of strict fiscal and monetary targets, the stability-oriented policy of the most important European member states France, Germany and Great Britain guaranteed an overall smooth functioning of the gold standard until World War I.

The Bretton Woods System (1944-1971)

With their accession to the Bretton Woods system, the member states agreed to stabilize their exchange rates to the Dollar and, if necessary, to intervene on the currency markets in order to limit exchange rate fluctuations to a certain margin. As key currency, the value of the Dollar was in turn tied to a fixed gold price. Already in the middle of the 1960s, the growing US deficit did no longer guarantee the gold backing of the US Dollar, de facto turning the Gold/ Dollar standard into a Dollar standard. Over time, different developments of productivity resulted in real distortions of the exchange rates, causing instability in the system.

The European Payments Union (1950-1958)

The European Payments Union (EPU) was introduced in 1950. It guaranteed international convertibility of Western European currencies in the Bretton Woods system. The EPU's core was its payment system, which was based on a multilateral compensation system where surpluses and deficits of all member states were centrally processed through the Bank for International Settlements (BIS). The payment of gold and dollars in the case of a deficit was a financial incentive for export-oriented growth, limited excessive deficits and made structural reforms more attractive.
The European Monetary System

"Snake in the Tunnel" (1972-1979)

In the framework of the so-called "snake in the tunnel", the member states agreed to stabilize the exchange rates of their currencies within a defined corridor. After the oil crises, uncoordinated national fiscal and monetary policies quickly led to diverging inflation rates, and finally also to the collapse of the agreement.

The Exchange Rate Mechanism of the EMS (1979-1993) The heart of the European Monetary System (EMS) was the Exchange Rate Mechanism (ERM), which limited fluctuations between exchange rates. After the complete liberalization of capital movements in 1986, national monetary policy partly lost its controlling function over macroeconomic developments. When the German Federal Bank raised its interest rates in reaction to the reunification boom, the other EMS states were forced to do the same despite their weak growth, in order to stabilize their currencies in relation to the Deutsche Mark, pushing their economies into a recession. The resulting imbalances finally led to the end of the EMS

The European Economic and Monetary Union (since 1999) In 1992, the member states of the European Union (EU) agreed on the establishment of the European Economic and Monetary Union (EMU). For Germany, the EMU is historically unique, since it is the first international currency regime which is based on completely and irrevocably fixed exchange rates, leaving no room for national monetary sovereignty. This means that EMU states with balance of payments problems no longer have the option to influence the their deficits or competitiveness through exchange rate or interest rate manipulations. A catalog with convergence criteria was agreed on. Member states fulfilling the criteria are obliged to participate in the common currency. In contrast to the Bretton Woods system or the EMS, there is no key currency which would grant one member state certain privileges. nal capital and trade flows. Also emerging countries will probably profit from their integration in fixed exchange rates regimes or regional monetary unions, since the resulting greater stability improves their attractiveness for international investors. ${ }^{8}$ Furthermore, a common supranational monetary policy may find it easier to build up reputation and guarantee independence from natio-

8 See Rogoff, K. et al. (2004): Evolution and Performance of Exchange Rate Regimes, IMD Occasional Paper No. 229, International Monetary Fund Washington, D.C 
nal governments than it would be possible for national monetary policies in emerging countries.

In a long-term perspective one should aim for a global monetary system consisting of several regional currency areas. But for the establishment of these regional currency areas the success conditions of regional common currencies need to be taken into account, as can be found in the theory of optimum currency areas (Box 2). In this context it should also be noted that some important national economies have not yet become involved in economic integration strategies. It would be helpful, if India and China took first steps towards joining a regional integration area or establishing a new one. But above all it must be guaranteed that exchange rate pegs between economic regions which extremely differ in their fundamentals are reduced. One means could be the revaluation of the currencies concerned in a new key currency system. We will enlarge upon that in the next section.

\section{The Question of the Key Currency}

At the moment, the US Dollar is relatively unchallenged as key and reserve currency; a major part of international trade and credit transactions are carried out in US Dollar, a big part (6I percent in 20IO) of currency reserves of the central banks are held in US Dollar. While the Euro gained importance in the period before the financial crisis (the share of international currency reserves in Euro increased from I8 to 27 percent between I999 and 20IO), the phase of the US Dollar appreciation after the Lehman bankruptcy has underlined the international importance of the Dollar as a safe haven and strengthened its role as most important international means of exchange. Medium-term, a mono-polar international global monetary system with a dominating Dollar is probably going to persist. The reasons are inertia effects, network externalities and the still unequalled size and liquidity of the US financial markets. ${ }^{9}$

China has been one of the advocates ${ }^{\mathrm{IO}}$ for a long-term promotion of the special drawing rights ${ }^{\mathrm{II}}$ (SDR) of the Inter-

9 See Lim, E.-G. (2006): The Euro's Challenge to the Dollar: Different Views from Economists and Evidence from COFER (Currency Composition of Foreign Exchange Reserves) and Other Data. IMF Working Paper WP/06/153, International Monetary Fund, Washington, D.C.

10 See Zhou, X. (2009): Reform of the International Monetary System, essay posted on the website of the People's Bank of China, 9 April. www.pbc.gov.cn/ english $/$ detail .asp?col=6500\&id $=178$

11 SDR are credit lines on currencies of IMF member states. The value of the SDR is based on a basket of the four most important currencies (US Dollar, Euro, Yen and Pound Sterling). It is not a currency in the sense of a means of exchange since there are no private markets for the trading of SDR. national Monetary Fund as central reserve asset in the international monetary system. They have been in use as artificial currency unit since ig 69 and could reduce the dependence of the monetary system on the monetary policy of the USA (or other big economic regions). ${ }^{\text {I2 }}$ As such, the current very expansive monetary policy of the Federal Reserve Bank causes inflation on the international capital and resource markets because the US Dollar de facto holds a monopoly as trade currency. But if SDR are really to play a global role, deep and liquid markets need be created for SDR - not only through increased issuing by the IMF, but also through the development of a private market for SDR. Furthermore, it is feared that in the case of only vague emission rules the stock of SDR might increase drastically. ${ }^{13}$ This would limit the direct control of the central banks over the circulating amount of money, thus also limiting their sovereignty.

Recently, the role of gold in an international monetary system became again the subject of debate. Theoretically, gold could be a logic store of value for international investors and central banks if trust in the US Dollar is declining. In practice, however, central banks worldwide have drastically reduced their share of gold reserves during the last century. The reasons are clear. Because of its physical properties, gold is considerably less suitable for emergency financial transactions (e.g. purchases of currencies to fend depreciation pressure against the US Dollar or the grant of 'emergency financial packages' by the IMF) than monetary means of payment. This applies also to the payment of imports or of interest on foreign debt. ${ }^{\mathrm{I}}$

A realistic long-term alternative to the current system is first and foremost the establishment of several currencies sharing the role of key and reserve currency. The US Dollar is probably going to lose some of its dominance and the Euro as well as the Chinese Renminbi will very likely gain in importance in the future. Such a process would strengthen the international monetary system at the end of the day, because international investments would be more equally spread and interest rate distortions would be reduced. The emitters of reserve currencies would be compelled to stricter monetary policy dis-

12 See Dorucci, E., McKay, J. (2011): The International Monetary System After the Financial Crisis. ECB Occasional Paper No. 123; Eichengreen, B. (2011): Exorbitant Privilege - The Rise and Fall of the Dollar and the Future of the International Monetary System. Oxford University Press, Oxford.

13 See Cooper, R.N. (2011): Is SDR Creation Inflationary? Report by Richard Cooper, Harvard University, as Independent External Consultant to the IMF, Washington, D.C., January 7.

14 See Eichengreen, 2011, I.c. 
Box 2

\section{The Optimum Currency Area Theory}

The Theory of Optimum Currency Areas (OCA theory) lists criteria according to which monetary integration makes sense for national economies. Typically, traditional OCA theory takes the advantages of monetary integration for granted (e.g. higher transparency or lower transaction costs on international goods and capital markets) and identifies conditions limiting the disadvantages of monetary integration - above all, the loss of autonomous monetary policy which could mitigate countryspecific employment fluctuations.

Mundell identifies factor mobility as the most important determinant for the cost of monetary integration: He argues that excess or too low demand for labor in the member states of the union can be compensated by migration; thus, stabilizing monetary policy is dispensable if high labor mobility is given.'

Mundell's seminal work was complemented by additional criteria: McKinnon points out the importance of the degree of openness: The more goods a country imports, the stronger is the influence of international goods prices on the domestic cost of living. Thus, the cost of the loss of national monetary policy is comparably low in this case, since the domestic central

1 Mundell, R.A. (1961): A Theory of Optimum Currency Areas. American Economic Review, 51 (4), 657-665 bank has less influence on price levels and employment. ${ }^{2}$ Kenen argues that a high degree of diversification within economies reduces the sensitivity of the member states' reaction on external influences; cyclical fluctuations are mitigated and stabilizing monetary policy is less of a necessity. Other criteria concern the fiscal-policy integration of member states, capital mobility between member states or the population's acceptance of integration.

Recent progress in macroeconomic research tends to challenge traditional OCA theory. Especially the loss of stabilizing monetary policy, which traditionally has been the most important disadvantage of monetary integration, is questionable under the assumption of rational expectations. Thus, more recent work on the OCA theory focuses less on the disadvantages of monetary integration, focusing more on the advantages of the establishment of a monetary union. In many cases, reduced uncertainty on goods and capital markets is identified as the central advantage of monitor integration. ${ }^{3}$

2 McKinnon argues strictly Keynesian and assumes that the central bank is free to choose any point on a stable Phillips curve. See McKinnon, R.I. (1963): Optimum Currency Areas. American Economic Review, 53 (4), 717-725.

3 Kenen, P.B. (1969): The Optimum Currency Area: An Eclectic View. In: R.A. Mundell, A.K. Swoboda (eds.): Monetary Problems of the International Economy, 41-60, The University of Chicago Press, Chicago. cipline in order to keep the status of reserve currency and the advantages of "exorbitant privilege"

\section{Policy for a New Global Monetary System}

A precondition for the transition to a multi-polar monetary system is the establishment of several currencies as international means of payment on the currency

15 "Exorbitant privilege" means the advantage of the emitter of the key and reserve currency to incur debts abroad at low interest rates, since the demand for bonds in the respective currency is quite high. At the same time, assets abroad yield high returns, because the high demand for the reserve currency results in higher interest payments. Another advantage for the key currency country is high money creation profit, since the amount of money in circulation is over-proportionally high markets. ${ }^{16}$ The US Dollar, the currency of the biggest national economic region with the most liquid markets, is going to be the primus inter pares in the medium term. The Euro with an economic region of similar importance holds the potential to become more attractive. This will probably take place once the euro zone has solved its debt crisis convincingly. China has already begun to encourage foreigners step by step to use the Renminbi (RMB) for goods and financial transactions. ${ }^{17}$ It is likely that this strategy will result in a higher attrac- 
tiveness of the currency for international investors and central banks. ${ }^{18}$

In order to make the monetary system less susceptible to the imbalances observed in the past which culminated in the financial crisis, further international coordination of monetary and currency policies is a necessity. It will be crucial that single countries do not try to gain an advantage by manipulating exchange rates or through inappropriate monetary and liquidity strategies. Because of the globalization of financial markets since the I990s, direct cross-border spill-over effects between national (excess) amounts of money have further increased. Because of international capital flows, increased amounts of money in one country lead to an increase of liquidity in the financial markets of other economies as well. This has also reduced the central banks' influence on the domestic money supply - making an international coordination even more important.

Experiences from the most recent and past financial crises show a clear correlation between capital mobility and crisis probability. ${ }^{\text {I9 }}$ If a country's balance of payments suffers from massive in- or outflow of capital, it needs to be checked whether corrective measures like interest or exchange rate adaptations can be introduced. Especially in emerging countries, the development of domestic financial and capital markets must be promoted in order to limit excessive in- and outflow of capital contributing to global imbalances. ${ }^{20}$ Additional symptomfighting measures (establishment of big currency reserves, introduction of capital movement controls, currency market interventions) can be helpful from time to time, too. However, they should only be used in addition to interest and exchange rate measures. Above all, a set of rules is required to regulate handling and form of capital movement controls. Based on this set of rules, efficient regulation as well as more effective consulting on the advantages and disadvantages of different intervention instruments would be possible. ${ }^{2 \mathrm{I}}$

\footnotetext{
18 Other candidates for key currencies are the Indian Rupee and the Brazilian Real. Both economies have to take on major restructuring tasks like China before their currencies can be used internationally.

19 Eichengreen, B. (2004): Capital Flows and Crises. Cambridge, London, MIT.

20 See Dell'Ariccia, G., di Giovanni, J., Faria, A., Kose, A., Mauro, P., Ostry, J.D., Schindler, M., Terrones, M. (2008): Reaping the Benefits of Financial Globalization. IMD Occasional Paper 264; Kose, A., Prasad, E., Rogoff, K., Wei, S. (2006): Financial Globalization: A Reappraisal. IMF Working Paper 06/189; Chinn, M.D., Ito, H. (2005): What Matters for Financial Development? Capital Controls, Institutions and Interactions. NBER Working Paper No. 11370; Chinn, M.D., Ito, H. (2008): East Asia and Global Imbalances: Savings, Investment and Financial Development. Paper prepared for the 18th Annual NBER-East Asian Seminar on Economics.

21 See IMF (2010): The Fund's Mandate - The Future Financing Role: Reform Proposals. IMF Staff Paper.
}

Conceptual faults of the financial authority need to be abolished, too. The discrepancy between mainly national regulatory authorities and more and more internationally oriented financial markets must be reduced through the creation of new institutions or the restructuring of existing bodies. They should not only monitor national economies, but also check the implications of contagion, synergy and feedback effects and be able to intervene when the need arises. Some steps towards this aim have already been taken: Bodies like the Mutual Assessment Group and the Financial Stability Board by the $\mathrm{G}_{2} \mathrm{O}$ as well as the IMF/World Bank's Financial Sector Assessment Program were created, which are to develop globally valid rules for financial stability and facilitate the implementation of national reforms for bank and financial market authorities with international support and coordination. On a European level, the Van Rompuy Task Force is currently working on an EU monitoring system for early detection of undesirable developments in the member states and specific recommendations for correction.

However, a reform of the financial regulatory bodies must also take into account that the, in some cases, enormous lack of information on financial and capital market activities needs to be solved. Frequent, detailed and timely publication of important financial indicators for example on payment balances, trade with derivatives, currency market dependencies and cross-border banking activities is essential for an early warning system. In this respect, there is still room for improvements.

It is crucial, however, that risks are not only detected, but that corrective measures can also be implemented better than in the past. The IMF for example should be given better intervention possibilities concerning decision-making processes of the receiving countries. Another central issue is a strengthened regional coordination of financial (and economic) policies. In this context, a stronger economic integration in the euro zone is desirable.

\section{Conclusion: Implications for European Policy Makers}

Further regional monetary integration (e.g. in the European, Asian or Latin American regions) with flexible exchange rates between the regions is, as described, the most likely and also the most advantageous scenario for the future international monetary system. Based on the described benefits of fixed exchange rates, European economic policy should in principle aim for an enlargement of the euro zone. This does, however, not mean to repeat the mistakes of the past and accept coun- 
tries with highly diverging economic performance. For the future of the EU, an economically homogenous currency area is probably of higher importance than a (still necessary) tightening of the fiscal convergence and stability criteria, since it mitigates the occurrence of macroeconomic imbalances. At the same time, German economic policy should support macroeconomic integration in other economic regions by taking on a mediating and consulting role in this context. Additionally, further global flexibilization of exchange rates should be an aim; in the short-term, this includes mainly the flexibilization of the pegged exchange rate between China and the USA.

The transition to a multi-polar currency system with other reserve currencies besides the US Dollar like the Euro and the Renminbi would probably entail significant advantages for the Euro area countries, since the existing unilateral dependence on the US Dollar on global financial markets could be reduced. From a European perspective, the newly formed monetary dominance of the G-2 (China and USA) needs to be tackled as well. Because of the much more expansionary monetary policy in the USA, this tends to work in favor of an appreciation of the Euro. Once the Euro gains the status of a key currency, stronger global demand for the Euro results in additional seigniorage revenues; in turn, a stability-oriented (and thus growth-friendly) monetary policy is needed to keep them.

In order to permanently establish the Euro as a key currency on capital markets besides the US Dollar, Europe must redesign the rules of the European Monetary Union. A strengthened EU governance framework has to include clear regulations for the handling of fiscal crises and provide preventive measures. Germany, for example, should work for better coordination of economic policies in the euro zone. It is a step forward that, in the framework of the so-called "European semester", EU member countries now need to submit their draft budgets to the European Commission half a year before their adoption. This way, the Commission has more control over possible violations of the stability and growth pact (SGP) and is able to take preventive action if the necessary. The lack of possibilities for sanctions in the case of SGP violations is still a problem, though. Significant improvements are still needed in this field. Realistically, a tightened SGP will only work with a stable European Union, with strong, democratically legitimized institutions and high acceptance among the people. It is only then that we can expect European governments to agree to further coordination and to waive parts of their national sovereignty.
The formation of macroeconomic imbalances inside the EU, as they can be observed in current account imbalances or competitive differences on the labor market, has caused instability in the past. Based on a planned amendment to the EU Treaty, the "proposal for a regulation on the prevention and correction of macroeconomic imbalances", the European Commission is to issue early warnings and propose corrective action in the future. However, there is the risk that the indicators for the identification of macroeconomic imbalances are so vaguely defined that the regulation will be less effective. The German government still has the possibility to influence this regulation to make it more effective by advocating for a clear and detailed list of indicators and threshold values (scoreboard). ${ }^{22}$

Additionally, global policy-makers are called to support the stabilization of capital markets - also by assigning clear tasks to the IMF and the G-20. An improved financial authority and financial market regulation, e.g. through new regulations on the monitoring of capital accounts, better publication of financial market indicators and, above all, improved enforceability of proposals correcting undesirable developments, would be first steps towards a crisis-proof global monetary system.

Prof. Dr. Ansgar Belke is Research Director for International Macroeconomics at DIW Berlin / abelke@diw.de

Dr. Kerstin Bernoth is Deputy Head of the Department for Macroeconomics/ kbernoth@diw.de

Dr. Ferdinand Fichtner is Acting Head of the Department for Forecasting and Economic Policy / ffichtner@diw.de

JEL: E02, E42, F33, F42, F53

Keywords: International Monetary System, Key Currency, Exchange Rate System, Financial Crisis, International Economic Policy.

Article first published as "Die Zukunft des internationalen Währungssystems", in: DIW Wochenbericht Nr. 37+38/2011. 